\title{
ANALISIS FUNGSI MANAJEMEN LOGISTIK DI BADAN PEMBERDAYAAN MASYARAKAT DAN KELUARGA BERENCANA KOTA SURABAYA
}

\author{
LOGISTICS MANAGEMENT FUNCTION ANALYSIS IN BOARD OF COMMUNITY EMPOWERMENT AND \\ FAMILY PLANNING SURABAYA
}

Paramita Boni Lestari, Setya Haksama

Fakultas Kesehatan Masyarakat, Universitas Airlangga, Surabaya

E-mail: paramitabonilestari@yahoo.co.id

\begin{abstract}
Board of Community Empowerment and Family Planning has the main task in a family planning and family welfare program.Logistics management was very importance to support that program. There were 17.020 syringes whichexpired but have not been destroyed in 2016. Author wanted to examine the logistics management function in Bapemas and KB. The variables were logistics planning, budgeting, procurement, receiption, storage, distribution, and elimination. The samples were two warehouse logistics officers. Data collection techniqueswere observation and indepth interview. Requirements planning used the formula of average usage per month multiplied by 3 or 24. The procurement process was done by request to BKKBN Province.Budgeting wasderived from two sources. The sources werestate and local fund. Reception and distribution process was appropriate with technical manual book. Storage facilities reached $94.1 \%$ of the BBKBN Centerstandard. While the general provisions saving reached $100 \%$. Eliminating logistics had not done since 2012. The recording process used the forms and books that have been standardized by National BKKBN office.Monitoring started from receipt, storage and distribution. That was done by Province BKKBN office. The conclusion of this research was the Implementation of all functions in accordance with the standards.
\end{abstract}

Keywords: logistics management function, family planning, distribution, procurement

\section{PENDAHULUAN}

Keluarga Berencana merupakan upaya untuk mengatur kelahiran anak, jarak serta usia ideal melahirkan. Salah satu upaya untuk menjamin keberlangsungan pelayanan Keluarga Berencana yaitu“Mewujudkan pembangunan yang berwawasan kependudukan dan mewujudkan keluarga kecil bahagia sejahtera". Alat kontrasepsi dan non alat kontrasepsi berfungsi untuk menunjang operasional program kependudukan dan keluarga berencana. Hal ini perlu didukung dengan pengelolaan alat kontrasepsi (alkon) dan non alat kontrasepsi (non alkon) yang profesional, efektif dan efisien.

Badan Pemberdayaan Masyarakat dan Keluarga Berencana Kota Surabaya (Bapemas dan KB Kota Surabaya) merupakan badan pemerintahan yang mempunyai tugas pokok di dalam bidang keluarga berencana dan sejahtera.
Salah satu tugas pokok Bapemas dan KB Kota Surabaya tahun 2016 adalah menyediakan sarana dan prasarana pelayanan kontrasepsi mantap dan kontrasepsi jangka panjang yang lebih terjangkau, aman, berkualitas serta merata skala kota. Oleh karena itu, diperlukan manajemen logistik yang baik agar alat kontrasepsi dan non alat kontrasepsi dapat tersalurkan ke semua fasilitas pelayanan kesehatan di Kota Surabaya.

Berdasarkan data Badan Pemberdayaan Masyarakat dan Keluarga Berencana Kota Surabaya tahun 2016, terdapat 17.020 spuit yang sudah melewati masa kadaluwarsa namun belum dimusnahkan. Oleh karena itu, penelitian ini akan mengkaji tentang pelaksanaan fungsi manajemen logistik di Badan Pemberdayaan Masyarakat dan Keluarga Berencana Kota Surabaya (Bapemas dan KB)berdasarkan standar BKKBN Pusat. 


\section{PUSTAKA}

\section{Supply Chain Management (SCM)}

Menurut Anwar (2011) dan Siagian (2012), SCM menunjukkan rantai panjang yang dimulai dari supplier sampai pelanggan. SCM membahas seluruh aktivitas dari suatu perusahaan mulai dari level strategis, level tactical, hingga level operasional. Pelaku utama dalam Supply Chain Management meliputi:

Chain 1:Supplier merupakan sumber yang menyediakan bahan pertama. Bahan pertama bisa berbentuk bahan baku, bahan mentah, bahan penolong, bahan dagangan, dan sebagainya. Jumlah supplier biasanya berjumlah cukup banyak.Chain 1-2: Manufacture adalah tempat memproses atau mengelola bahan baku mulai dari bahan mentah hingga menjadi bahan jadi. Chain 1-23:Distributor, barang yang telah dihasilkan oleh manufacture kemudian disalurkan kepada pelanggan.

Chain 1-2-3-4: retail outlet, pedagang besar biasanya mempunyai fasilitas gudang penyimpanan sendiri atau menyewa dari pihak lain. Gudang ini digunakan untuk menyimpan barang sebelum disalurkan lagi ke pihak pengecer. Chain 1-2-3-4-5: Customers, pada pengecer atau retailers menawarkan barangnya langsung kepada para pelanggan.

Implementasi SCM membutuhkan dukungan dari berbagai pihak mulai dari internal (seluruh manajemen puncak) dan eksternal (seluruh partner yang ada). Berikut ini merupakan hambatan- hambatan yang akan dialami dalam implementasi SCM menurut Anwar (2011).

Hambatan pertama yaitu increasing variety of products.Banyaknya jenis produk dan jumlah yang tidak menentu dari masing-masing produk membuat produsen semakin kesulitan dalam memuaskan keinginan dari konsumen.

Hambatan kedua yaitu decreasing product life cycles. Daur hidup sebuah produk yang menurun, membuat perusahaan semakin kesulitan dalam mengatur strategi pasokan barang. Daur hidup produk diartikan sebagai umur produk tertentu di pasaran

Hambatan ketiga adalah increasingly demand customer.Supply chain management berusaha mengatur peningkatan permintaan secara cepat, karena customer semakin menuntut pemenuhan permintaan yang secara cepat walaupun permintaan itu sangat mendadak dan bukan merupakan produk yang standart.

Hambatan terakhir adalah globalization. Globalisasi membuat supply chain semakin rumit dan kompleks karena pihak-pihak yang terlibat dalam supply chain tersebut mencakup pihak-pihak di berbagai negara.

\section{Manajemen Logistik}

Menurut Bowersox, DJ (2006) dalam Rizky (2012), manajemen logistik adalah proses pengelolaan yang strategis terhadap pemindahan dan penyimpanan barang, suku cadang, barang jadi dari para supplier kepada para pelanggan. 
Menurut Seto dkk (2004) dalam Khasanah (2010), manajemen pengelolaan obat mempunyai fungsi manajemen logistik sebagai berikut:

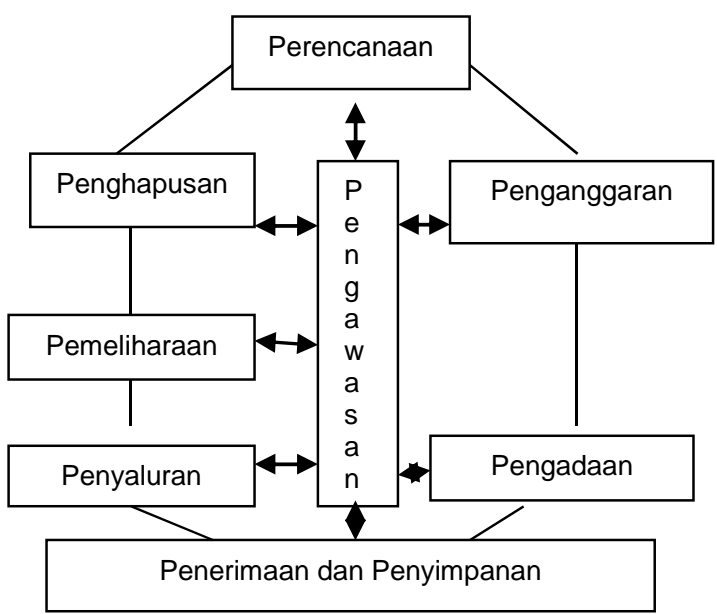

Gambar 1. Siklus Pengelolaan di bidang logistik (Seto dkk dalam Khasanah, 2010)

Perencanaan adalah tindakan dalam pemenuhan kebutuhan yang menyangkut proses memilih, seleksi, dan menetapkan jenis dan jumlah logistik.

Pengadaaan adalah kegiatan operasional untuk memenuhi kebutuhan yang telah ditetapkan berdasarkan proses perencanaan.

Penganggaran adalah perumusan perincian kebutuhan dalam skala mata uang.

Penerimaan adalah kegiatan menerima logistik oleh petugas gudang dari petugas pengirim barang sesuai dengan jumlah barang yang di minta.

Penyimpanan dilakukan untuk menjaga kualitas barang sehingga tidak mengalami kerusakan.

\section{METODE}

Penelitian ini merupakan penelitian deskriptif observasional dengan desain penelitian cross sectional. Waktu penelitian dilakukan pada tanggal 15 Agustus 2016s/d 9 September 2016. Penelitian dilakukan di unit logistik Bapemas dan KB Kota
Surabaya. Sampel pada penelitian ini adalah Bendahara barang sebanyak 2 orang. Teknik pengambilan sampel menggunakan total sampling. Pengumpulan data yang dilakukan dengan cara observasi dan indepth interview. Observasi dilakukan pada variabel penyimpanan, penyaluran, pencatatan dan pelaporan. Sedangkan indepth interview dilakukan pada variabel supply chain management,perencanaan, pengadaan, penganggaran, penerimaan, pemusnahan, pemantauan dan evaluasi. Analisis data menggunakan distribusi frekuensi.

\section{HASIL DAN PEMBAHASAN}

\section{Supply chain management}

Supply chain di Bapemas dan KB Kota Surabaya dibagi menjadi 2 berdasarkan sumber dana yang diperoleh Bapemas dan KB kota Surabaya. Supply Chain berdasarkan sumber dana APBN dapat dilihat pada gambar 2 di bawah ini:

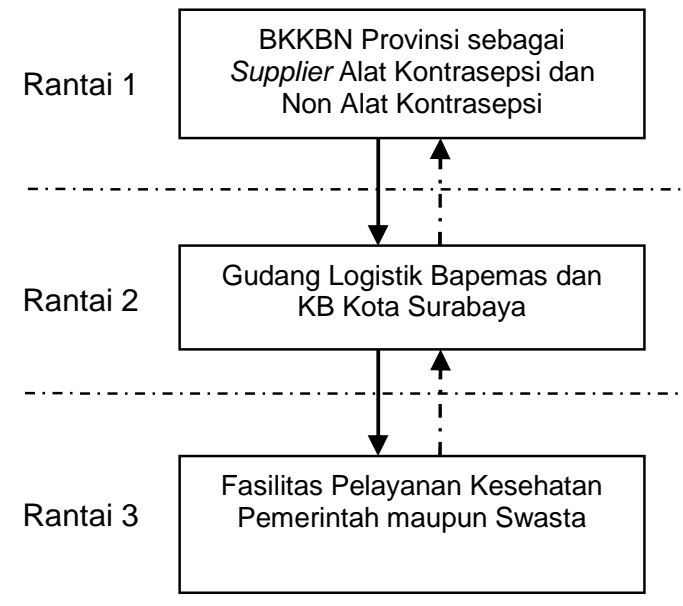

Gambar 2. Supply Chain Manajemen di Bappemas dan KB Kota Surabaya dengan Sumber dana APBN

BKKBN Provinsi Jawa Timur bertindak sebagai supplieryang menyalurkan alkon dan non alkon ke Bapemasdan KB Kota Surabaya sesuai 
dengan no Batch kota. Sedangkan Bapemas dan KB kota Surabaya bertindak sebagai supplier yangmenyalurkan alat kontrasepsi dan non alat kontrasepsi ke fasilitas pelayanan kesehatan.

Supply Chain berdasarkan sumber dana APBD dapat dilhat pada gambar di bawah ini;

Rantai 1

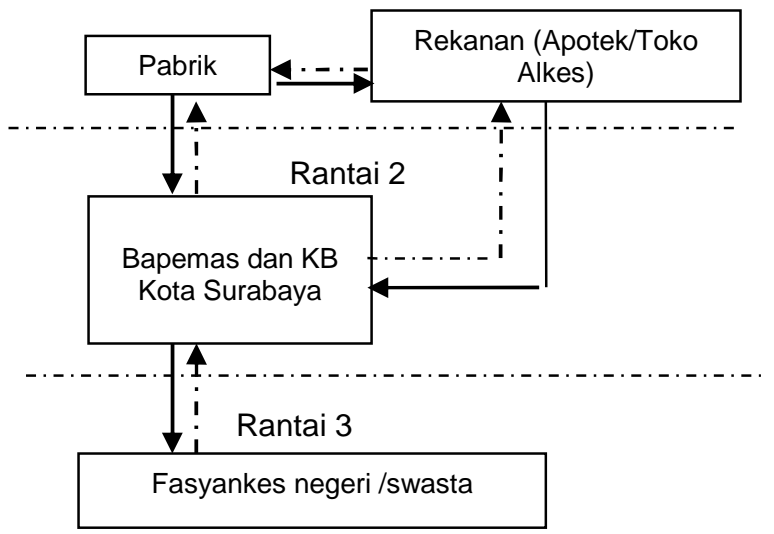

Gambar 3. Supply Chain Manajemen di Bappemas dan KB Kota Surabaya dengan sumber dana APBN

Bapemas dan KB dapat membeli ke apotek atau toko alat kesehatan yang telah ditunjuk. Namun Bapemas dan KB dapat langsung membeli ke pabrik tanpa melalui toko alat kesehatan atau apotek. Bapemas dan KB Kota Surabaya bertindak sebagai supplier yang menyalurkan alat kontrasepsi dan non alat kontrasepsi ke fasilitas pelayanan kesehatan.

\section{Perencanaan}

Proses perencanaan yang dilakukan oleh Bapemas dan KB Kota Surabaya menggunakan metode konsumsi. Ada tiga metode persediaan yang digunakan di Bapemas dan KB Kota Surabaya yaitu persediaan minimum, persediaan maksimum dan persediaan maksimum dikurangi stok akhir.

Persediaan minimum di hasilkan dari ratarata pemakaian per bulan dikalikan 3 (untuk 3 bulan). Persediaan maksimum dihasilkan rata-rata pemakaian per bulan dikalikan 24 (untuk 2 tahun). Dari ketiga metode itu yang paling sering digunakan adalah persediaan minimum dan persediaan maksimum

\section{Pengadaan}

Pengadaan alkon dan non alkon di Bapemas dan KB Kota Surabaya dilakukan dengan melakukan proses permintaan kepada BKKBN Provinsi. Proses permintaan sudah sesuai dengan petunjuk teknis BKKBN Pusat (2011). Berikut usulan flowchart permintaan logistik di Bapemas dan KB Kota Surabaya:

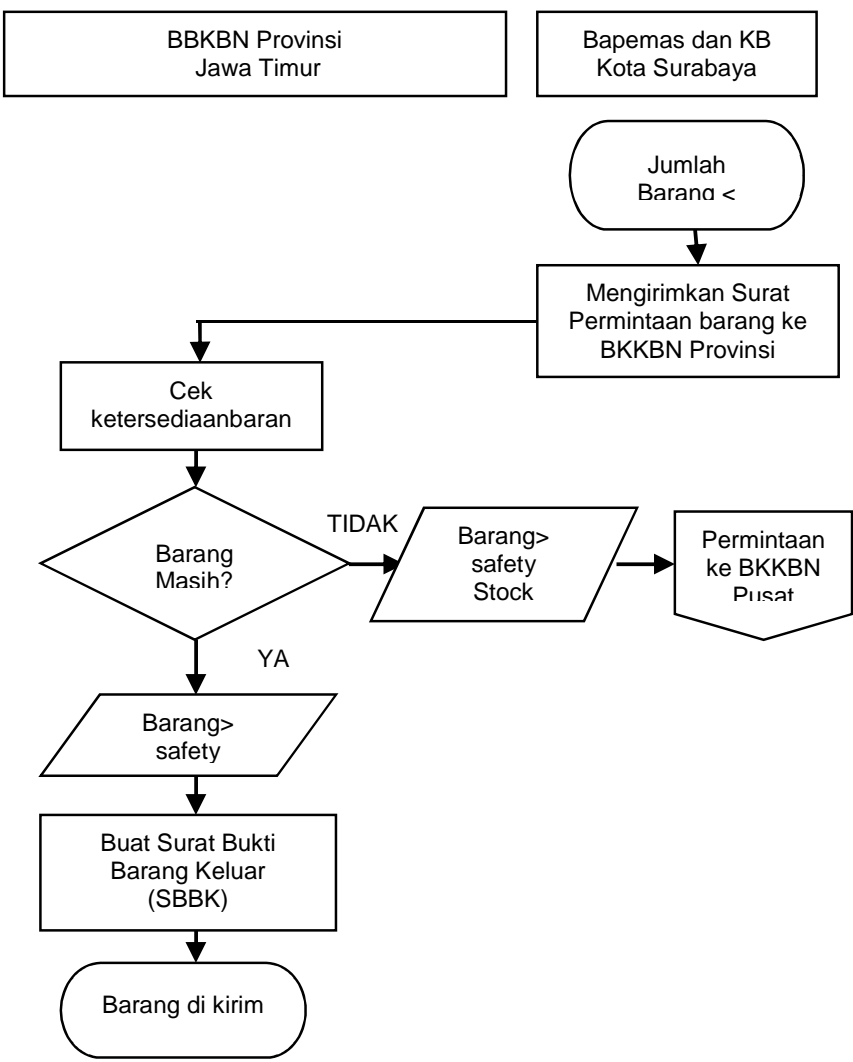

Gambar 4. Flowchart Permintaan Alkon dan Non Alkon dari Bapemas dan KB Kota Surabaya Ke BKKBN Provinsi

\section{Penganggaran}

Sumber dana yang digunakan untuk pengadaan logistik di Bapemas dan KB adalah APBN dan APBD. Logistik yang didanai oleh APBD adalah logistik yang tidak dikeluarkan oleh BKKBN 
Provinsi namun dibutuhkan oleh Klinik KB dan

Fasilitas Pelayanan Kesehatan baik negeri maupun swasta. Logistik tersebut antara lain Amoxicillin 500 mg dan Asam Mefenamat 500 mg.

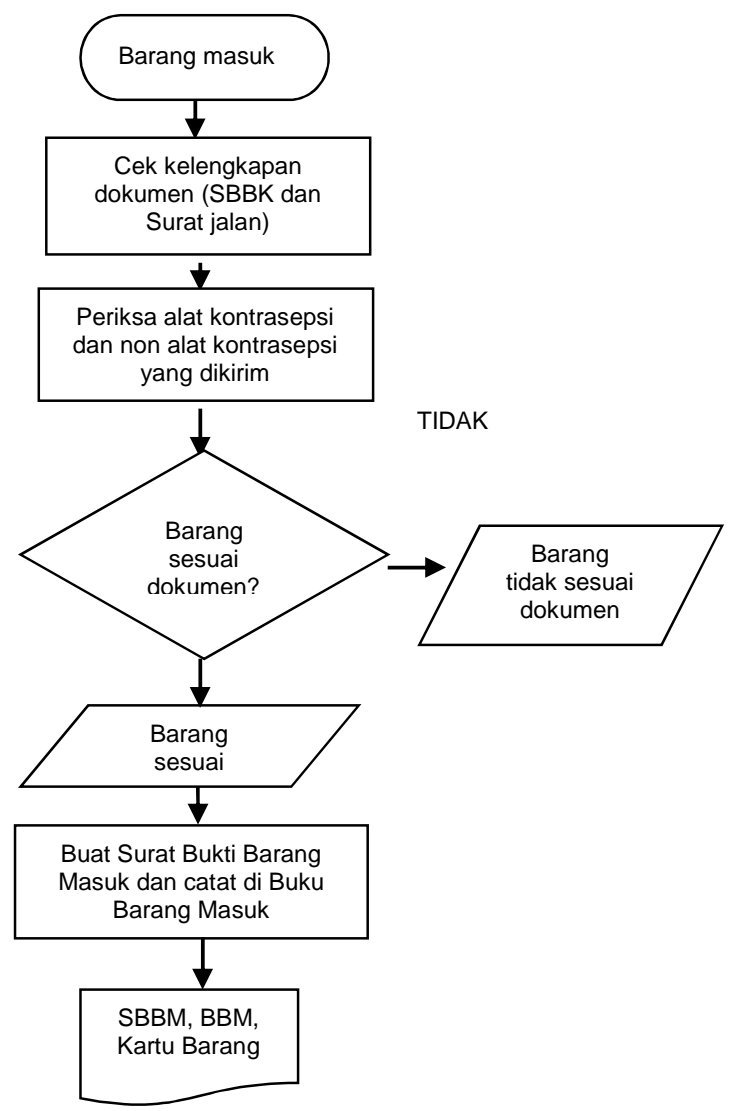

Gambar 5. Flowchart proses penerimaan barang di Bapemas dan KB Kota Surabaya

\section{Penerimaan}

Penerimaan logistik dilaksanakan oleh panitia penerima barang dan bendahara barang pada jam kerja. Proses penerimaan sudah sesuai dengan petunjuk teknis BKKBN Pusat (2011). Gambar 5 menunjukkan usulan flowchart penerimaan logistik di Bapemas dan KB Kota Surabaya

\section{Penyimpanan}

Prosedur penyimpanan yang dilakukan di Bapemas dan KB Kota Surabaya merupakan prosedur penyimpanan First In First Out (FIFO) dan First Expired First Out (FEFO). Berdasarkan hasil observasi terhadap sarana prasana penyimpanan alat kontrasepsi dan non alat kontrasepsi didapatkan hasil sebagai berikut:

Tabel 1. Hasil Observasi Sarana Prasarana Penyimpanan Alat Kontrasepsi Dan Non Alat Kontrasepsi Di Bapemas Dan KB Kota Surabayatahun 2016

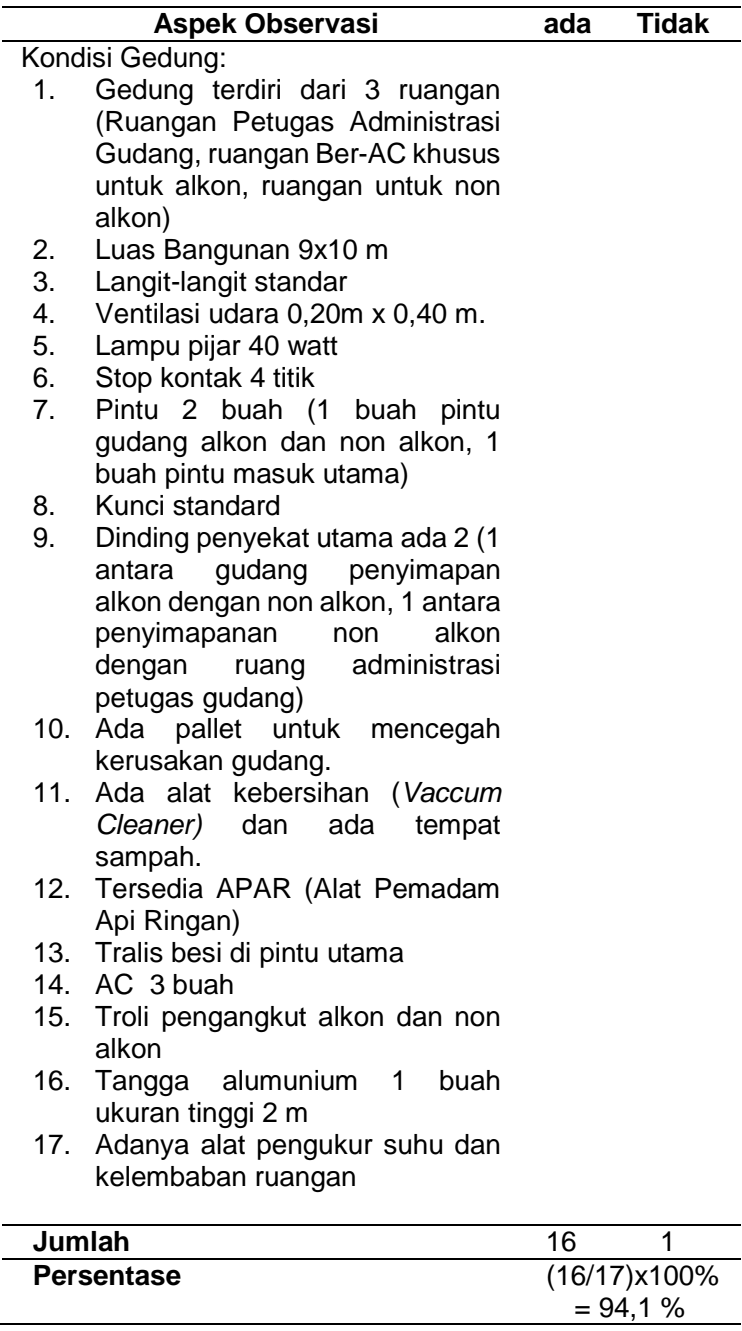

Berdasarkan tabel observasi di atas, sarana dan prasarana penyimpanan alat kontrasepsi dan non alat kontrasepsi di Bapemas dan KB Kota Surabaya sudah memenuhi syarat dari BKKBN Pusat (2012) sebesar 94,1\%. Namun ada satu alat yang belum dimiliki oleh gudang Bapemas dan KB Kota Surabaya yaitu alat pengukur suhu dan kelembaban udara. 
Berdasarkan hasil indept interview dengan

Kepala Sub Bidang Keluarga Berencana, permintaan alat ini sudah dilakukan sejak lama namun belum mendapat respon dari BKKBN pusat. Sedangkan ketentuan umum terkait penyimpanan dapat dilihat pada tabel di bawah ini:

Tabel 2. Hasil Observasi Ketentuan Umum Dalam Penyimpananalat Kontrasepsi Dan Non Alat Kontrasepsi Di Bapemas Dan KB Kota SurabayaTahun 2016

\begin{tabular}{|c|c|}
\hline \multirow{2}{*}{\multicolumn{2}{|c|}{$\begin{array}{c}\text { Aspek Observasi } \\
\text { Ketentuan umum dalam penyimpanan: }\end{array}$}} \\
\hline & \\
\hline $\begin{array}{l}\text { 1. Tinggi susunan untuk kardus atau } \\
\text { box }<2 \mathrm{~m}\end{array}$ & $\sqrt{ }$ \\
\hline $\begin{array}{l}\text { 2. Jarak antara pallet dan tembok > } \\
30 \mathrm{~cm}\end{array}$ & $\sqrt{ }$ \\
\hline $\begin{array}{l}\text { 3. Lebar penataan alkon selebar } \\
\text { ukuran } 2 \text { box }\end{array}$ & $\sqrt{ }$ \\
\hline $\begin{array}{l}\text { 4. Setiap baris susunan alkon adalah } \\
5 \text { atau } 10 \text { karton }\end{array}$ & $\sqrt{ }$ \\
\hline $\begin{array}{l}\text { 5. Suhu udara untuk penyimpanan } \\
\text { alkon: }\end{array}$ & \\
\hline a. IUD $<25$ derajat celcius & $\sqrt{ }$ \\
\hline b. Kondom < 25 derajat celcius & $\sqrt{ }$ \\
\hline c. Pil $<25$ derajat celcius & $\sqrt{ }$ \\
\hline $\begin{array}{l}\text { d. Suntikan } 15 \mathrm{~s} / \mathrm{d} 25 \text { derajat } \\
\text { celcius }\end{array}$ & $\sqrt{ }$ \\
\hline $\begin{array}{l}\text { e. Implant } 15 \mathrm{~s} / \mathrm{d} 25 \text { derajat } \\
\text { celcius. }\end{array}$ & $\sqrt{ }$ \\
\hline $\begin{array}{l}\text { Penyimpanan alkon dan non alkon } \\
\text { dikelompokkan berdasarkan dengan } \\
\text { jenis barang. }\end{array}$ & $\sqrt{ }$ \\
\hline Menulis di kartu Persediaan Barang & $\sqrt{ }$ \\
\hline Menulis di Kartu Barang & $\sqrt{ }$ \\
\hline Jumlah & 12 \\
\hline Persentase & $\begin{array}{l}(12 / 12) \times 100 \% \\
=100 \%\end{array}$ \\
\hline
\end{tabular}

Berdasarkan tabel di atas Bapemas dan KB sudah memenuhi syarat penyimpanan dari BKKBN Pusat (2012) sebesar 100\%. Hal ini menunjukkan bahwa syarat penyimpanan alat kontrasepsi dan non alat kontrasepsi di Bapemas dan KB Kota Surabaya sudah sesuai dengan standar dari BKKBN Pusat (2012).

\section{Pemusnahan}

Berdasarkan hasil indepth interview dengan Kepala Sub Bidang Keluarga Berencana, pemusnahan alat kontrasepsi dan non alat kontrasepsi di Bapemas dan KB Kota Surabaya sudah tidak dilakukan lagi sejak tahun 2012. Hal ini dikarenakan belum adanya tempat untuk pemusnahan alat kontrasepsi dan non alat kontrasepsi.

Selain itu pemusnahan yang pernah dilakukan oleh Bapemas dan KB Kota Surabaya pernah mendapatkan komplain dari masyarakat mengenai limbah yang ditimbulkan dari proses pemusnahan. Alat non kontrasepsi yang belum dimusnahkan dapat dilihat pada tabel di bawah ini

Tabel 3. Alat Non Kontrasepsi di luar masa kadaluwarsa

\begin{tabular}{|c|c|}
\hline Barang & Faktor penyebab \\
\hline Spuit 3cc & $\begin{array}{l}\text { Banyaknya spuit 3cc yang tidak } \\
\text { terpakai dikarenakan fasilitas } \\
\text { kesehatan mengajukan keluhan } \\
\text { mengenai kualitas spuit yang tidak } \\
\text { bagus. }\end{array}$ \\
\hline $\begin{array}{l}\text { Aquabidest } \\
\text { Injeksi }\end{array}$ & $\begin{array}{l}\text { Pihak BKKBN Provinsi sudah mengirim } \\
\text { barang namun Fasyankes menolak } \\
\text { untuk menerima barang tersebut } \\
\text { karena aquabidest injeksi ini tidak } \\
\text { diperlukan lagi untuk mengencerkan } \\
\text { lidocaine. }\end{array}$ \\
\hline $\begin{array}{l}\text { Thiamek } 500 \\
\text { mg }\end{array}$ & $\begin{array}{l}\text { Pihak BKKBN Provinsi mengirim jenis } \\
\text { antibiotik yang tidak sesuai dalam } \\
\text { pelayanan KB. }\end{array}$ \\
\hline Bethadine & $\begin{array}{l}\text { Waktu pengiriman barang yang sangat } \\
\text { dekat dengan masa kadaluarsa } \\
\text { barang. Sehingga r untuk } \\
\text { pendistribusiannya sudah melampaui } \\
\text { masa kadaluarsa. }\end{array}$ \\
\hline
\end{tabular}

Perbekalan farmasi yang kadaluwarsa

umumnya tidak menimbulkan ancaman yang serius terhadap kesehatan masyarakat atau lingkungan. Namun metode pembuangan yang tidak tepat dapat membahayakan jika mengakibatkan pencemaran terhadap air.Permasalahan yang sama terkait penghapusa logistik yang belum berjalan ditemukan oleh Fannya (2011) di Puskesmas Biaro.

Dampak pembuangan air limbah yang tidak tepat meliputi kontaminasi air minum, terlepasnya polutan toksik ke udara, dan diambilnya logistik kadaluwarsa untuk di jual kembali ke masyarakat umum(WHO,1999). 
Melihat dampak yang ditimbulkan sangat berbahaya maka perlu dilakukan metode untuk pembuangan limbah yang tepat. Berikut beberapa metode pembuangan limbah farmasi yang direkomendasikan oleh WHO (1999):

Rekomendasi pertama yaitu pengembalian ke donatur atau pabrik pembuat.Logistik harus dipilih terlebih dahulu untuk dikembalikan lagi ke pabik atau donatur.Logistik yang dapat dikembalikan lagi ke pabrik atau donatur adalah logistik yang dapat menimbulkan masalah dalam pembuangannya.

Rekomendasi kedua yaitu To Landfill (mengubur) berarti menempatkan limbah langsung ke lokasi pembuangan di tanah tanpa pengolahan atau persiapan sebelumnya. Landfill merupakan metode paling tua dan paling banyak digunakan untuk pembuangan limbah padat.

Rekomendasi ketiga yaitu encapsulation. Encapsulation (penyegelan limbah) berarti menjadikan limbah farmasi ke dalam bentuk padat dalam drum plastik atau baja. Drum harus dibersihkan sebelum digunakan dan sebelumnya tidak boleh berisi materi berbahaya atau yang mudah meledak. Rekomendasi keempat yaitu Inertization. Inertization adalah bentuk lain dari encapsulation. Metode ini memerlukan pelepasan materi, kertas, kardus dan plastik kemasan dari limbah farmasi.

Rekomendasi kelima yaitu Insinerasi suhu tinggi oleh pabrik industri. Pabrik Industri yang menggunakan insenerator suhu tinggi yaitu pabrik semen, pembangkit listrik bertenaga batubara, atau pabrik peleburan logam. Metode ini menggunakan tungku yang beroperasi pada suhu lebih $850^{\circ} \mathrm{C}$.
Dengan begitu, pemanfaatan pabrik industri memberikan alternatif yang murah dan terjangkau.

Rekomendasi terakhir yaitu penguraian kimia. Jika insenerator tidak tersedia, teknik penguraian kimia dapat digunakan sesuai dengan rekomendasi pabrik pembuatnya. Metode ini dapat dilakukan dengan pengawasan tenaga ahli kimia. Setelah dilakukan penguraian kimia maka dilanjutkan dengan pembuangan atau penguburan(landfill).

Setiap metode mempunyai kekurangan dan kelebihan. Penggunaan metode tertentu juga harus disesuaikan dengan kondisi organisasi. Dari beberapa rekomendasi tersebut penulis merekomendasikan pemakaian metodelnsinerasi suhu tinggi oleh pabrik industri.Metode ini merupakan metode yang paling murah dan terjangkau dibandingkan metode lain. Rekomendasi ini didasarkan pada sumber dana yang digunakan lebih banyak bersumber dari APBN.

\section{Penyaluran}

Menurut hasil observasi proses penyaluran alat kontrasepsi dan non alat kontrasepsi sudah sesuai dengan petunjuk teknis BKKBN Pusat (2012). Penyaluran dilakukan ketika fasilitas pelayanan kesehatan baik swasta maupun negeri melakukan permintaan ke Bapemas dan KB Kota Surabaya. Jumlah alat kontrasepsi dan non alat kontrasepsi akan dikirimkan sesuai jumlah barang yang tersedia di gudang Bapemas dan KB Kota Surabaya. Petugas gudang dan bendahara barang akan menganalisis permintaan dan jumlah safety stock di Bapemas dan KB Kota Surabaya. Berikut merupakan usulan flowchart proses penyaluran alat kontrasepsi dan non alat kontrasepsi: 


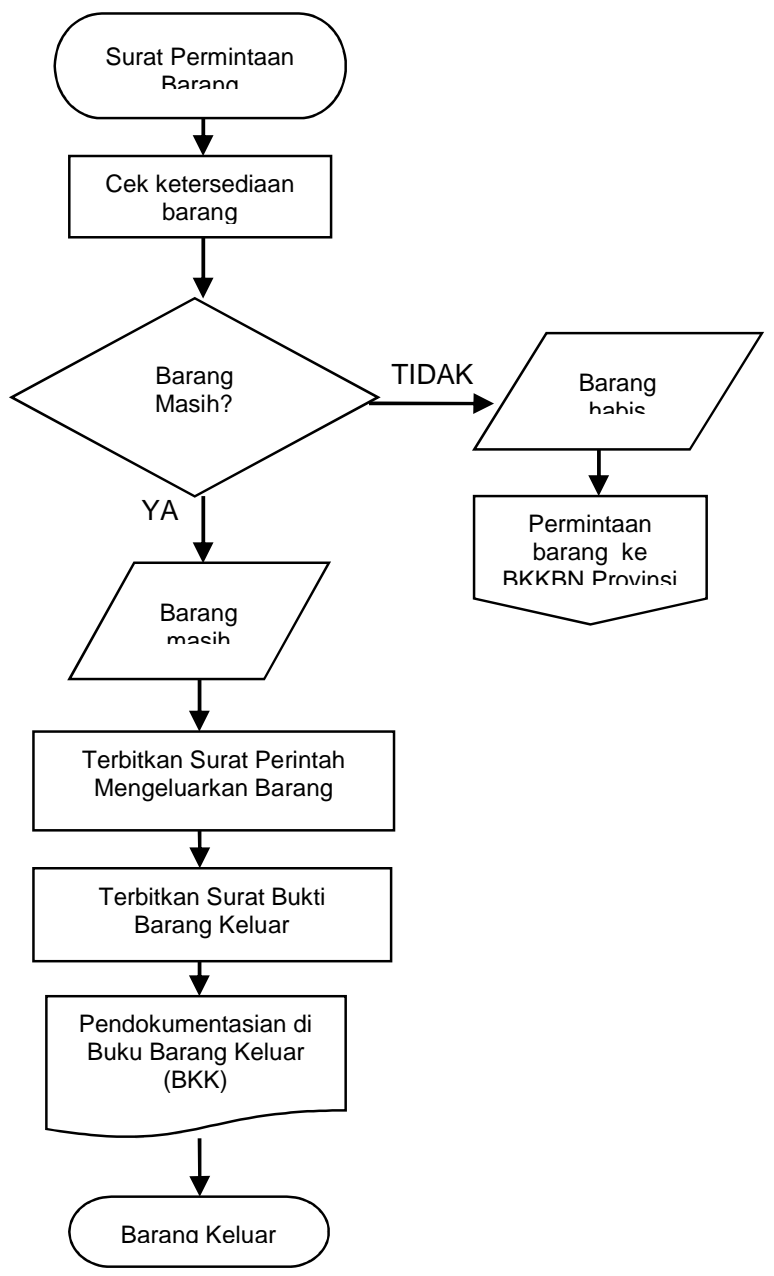

Gambar 6.Flowchart penyaluran alat kontrasepsi dan non alat kontrasepsi di Bapemas dan KB Kota Surabaya

\section{Pencatatan}

Pencatatan merupakan kegiatan perekaman data dalam bentuk tulisan ke dalam perangkat kerja yang telah di standarisasi. Formulir yang digunakan dalam pencatatan di Bapemas dan KB Kota Surabaya adalah sebagai berikut: 1) Formulir permintaan alkon dan non alkon, 2) Surat Perintah Mengelurkan Barang (SPMB), 3) Berita Acara Penerimaan Barang (BAPB), 4)Surat bukti Barang Masuk (SBBM), 5)Surat Bukti Barang Keluar (SBBK), 6) Berita Acara Penyerahan dan Penerimaan Barang Persediaan Alkon dan non Alkon.
Buku dan Kartu yang dipergunakan dalam pencatatan alkon dan non alkon yaitu: 1) Buku Barang masuk (BBM), 2) Buku Barang keluar (BBK), 3) Buku Surat Perintah Mengeluarkan Barang (SPMB), 4) Kartu Persediaan Barang, dan 5) Kartu Barang.

\section{Pelaporan}

Pelaporan merupakan kegiatan lanjutan dari pencatatan, sebagai bentuk pertanggungjawaban tertulis dari pelaksanaan tugas dan fungsi secara periodik tentang pengelolaan gudang termasuk didalamnya alkon dan non alkon.

Kegiatan pelaporan alkon dan non alkon dilaksanakan pada waktu bulanan dan per semester. Bentuk laporan bulanan dituangkan dalam bentuk laporan bulanan persediaan alkon (F/V/KB). Laporan bulanan ini diserahkan kepada BKKBN Provinsi Jawa Timur. F/V/KB berisi tentang laporan ketersediaan barang alat kontrasepsi saja.

Bentuk laporan yang dilaporkan secara 6 bulan sekali ini dituangkan dalam bentuk laporan stock opname. Laporan stock opname berisi mengenai ketersediaan alat kontrasepsi maupun non alat kontrasepsi. Kegiatan pelaporan dan pencatatan yang dilakukan di Bapemas dan KB kota Surabaya sudah sesuai dengan penelitian yang dilakukan Panjaitan (2014) di BKKBN Provinsi Sulawesi Utara.

\section{Pemantauan dan evaluasi}

Pemantauan di Bapemas dan KB kota Surabaya dilakukan oleh BKKBN Provinsi. Tidak ada periode waktu yang digunakan untuk pemantauan yang oleh BKKBN Provinsi. Pemantauan yang dilakukan BKKBN Provinsi terhadap Bapemas dan 
KB Kota Surabaya meliputi pemantauan terhadap kegiatan penerimaan, penyimpanan, penyaluran, pencatatan dan pelaporan.

\section{SIMPULAN}

Pelaksaanan fungsi manajemen logistik di Bapemas dan KB Kota Surabaya sudah berjalan dengan baik kecuali pemusnahan logistik.

Perencanaan. Perencanaan kebutuhan alat kontrasepsi dan non alat kontrasepsi dihitung dengan menggunakan persediaan minimum dan maksimum.

Penganggaran. Sumber dana pengadaan logistik diperoleh dari 2 sumber dana yaitu APBN dan APBD.

Pengadaan. Pengadaan logistik alat kontrasepsi dan non alat kontrasepsi dilakukan dengan pengajuan permintaan kepada BKKBN Provinsi Jawa Timur.

Penerimaan. Penerimaan logistiksudah sesuai dengan buku petunjuk teknis BKKBN Pusat.

Penyimpanan. Proses penyimpanan menggunakan sistem FIFO dan FEFO. Sarana dan prasarana penyimpanan sudah sesuai dengan standar BKKBN Pusat sebesar $94,1 \%$, namun belum adanya alat pengukur suhu dan kelembaban ruangan. Penulis memberikan saran kepada Instansi untuk melakukan penyediaan Thermo-Hygrometer, sehingga pemantauan suhu dan kelembaban ruangan penyimpanan dapat dilakukan dengan mudah dan akurat.

Penyaluran. Penyaluran alat kontrasepsi dan non alat kontrasepsi dari Bapemas dan KB Kota Surabaya ke fasilitas kesehatan kota Surabaya sudah sesuai dengan petunjuk teknis BKKBN Pusat.
Pemusnahan. Pemusnahan alat kontrasepsi dan non alat kontrasepsi sudah tidak dilakukan lagi sejak tahun 2012. Terdapat kendala dalam proses pemusnahan yaitu belum adanya tempat pemusnahan. Penulis merekomendasikan kepada instansi untuk bekerja sama dengan industri yang memiliki insenerator suhu tinggi dalam pemusnahan logistik.

Pencatatan dan pelaporan. Pencatatan dilakukan dengan menggunakan formulir dan buku yang telah distandarisasi oleh BKKBN Pusat. Pelaporan dilakukan setiap 1 bulan dan 6 bulan sekali ke BKKBN Provinsi.

Pemantauan dan evaluasi. Pemantauan dan evaluasi di Bapemas dan KB Kota Surabaya dilakukan oleh BKKBN Provinsi Jawa Timur. Pemantauan dilakukan pada poses penerimaan barang, penyimpanan dan penyaluran logistik.

\section{DAFTAR PUSTAKA}

Anwar, SN. (2011). Manajemen Rantai Pasokan (Supply Chain Management) Konsep dan Hakikat.Jurnal Dinamika Informatika, Vol 3 No $2 . \quad$ [e-jurnal]. doi: http://www.unisbank.ac.id/ojs/index.php/fti2/a rticle/view/1315/531

Bapemas dan KB. (2016). Profil Badan Pemberdayaan Masyarakat Kota Surabaya. Surabaya: Bapemas dan KB Kota Surabaya.

BKKBN. (2011). Petunjuk Teknis: Perencanaan Kebutuhan Alat dan Kontrasepsi dan Non Alat Kontrasepsi. Jakarta: Badan Kependudukan dan Keluarga Berencana Nasional.

BKKBN. (2012).Petunjuk Teknis: Penerimaan, Penyimpanan dan Penyaluran Alat/ Obat Kontrasepsi dan Non Alat Kontrasepsi Program KB Nasional. Jakarta: Badan Kependudukan dan Keluarga Berencana Nasional.

Fannya, P. (2011). Evaluasi Pelaksanaan Manajemen Logistik Alat Kesehatan Di Puskesmas Biaro Kabupaten AGAM Tahun 2011.Skripsi. Fakultas Kedokteran Universitas Andalas Padang. Retrieved from http://repository.unand.ac.id/17545/1/skripsi_ puteri.pdf 
Khasanah, U. (2010). Analisis Manajemen Logistik Obat Dalam Perencanaan, Pengendalian Persediaan, Safety Stock, Dan Reorder Point.Skripsi. Fakultas Kesehatan Masyarakat Unair.

Panjaitan, R., Goenawi, L., Lolo, W.. (2014). Pengelolaan Alat dan Obat Kontrasepsi di Badan Kependudukan Keluarga Berencana Nasional (BKKBN) Provinsi Sulawesi Utara. Jurnal Ilmiah Pharmacon, Vol 3 No 3. [ejournal]:Pp. 230-234. doi: http://ejournal.unsrat.ac.id/index.php/pharma con/article/viewFile/5423/4930

Rizky, M. A. (2012). Pengukuran Kinerja Supply Chain Management Pada PT. Caraka Purnama Abadi Pasuruan Dengan menggunakan Metode Score. Skripsi.Fakultas Ekonomi dan Bisnis Unair.
Siagian, Y. (2012). Supply Chain Management. [ebook] Grasindo. Retrieved fromhttps://books.google.co.id/books?hl=id\&l $r=\& i d=s t W D 5 P w g h R E C \& o i=f n d \& p g=P R 12 \& d$ $\mathrm{q}=$ supply+chain+management+adalah\&ots= WwO-bjqtL3\&sig $=$ vONexbUlvsAaDWj7OBGb-

V7qJk\&redir_esc=y\#v=onepage\&q=supply\% 20 chain $\% 20$ management $\% 20$ adalah $\& \mathrm{f}=$ false

WHO. (1999). Guidelines For Safe Disposal Of Unwanted Pharmaceuticals In And After Emergencies. Switzerland: World Health Organization. Retrieved fromhttp://www.who.int/water_sanitation_hea Ith/medicalwaste/unwantpharm.pdf 